\title{
Effects of Coating Conditions on Release Profiles of Controlled Release Granules Coated with Water Insoluble Polymer*
}

\author{
Shigeru TASHima, Kohei Matsumoto, Iwao Ando, \\ Reiji TAKEDA and Tomonori SHIRAISHI** \\ Aburahi Laboratories, Shionogi \& Co., Ltd., Koka-cho, Koka-gun, \\ Shiga 520-3423, Japan \\ **Laboratory of Plant Pathology and Genetic Engineering, College of Agriculture, Okayama University, \\ Tsushimanaka, Okayama \\ 700-8530, Japan
}

(Received November 20, 1998; Accepted February 23, 1999)

\begin{abstract}
We prepared capsule-type controlled release granules coated by water insoluble polymer, in which metominostrobin was used as a model agrochemical. In this study, the effects on release profiles of a) coating processes and b) content of polymer were evaluated at the equal amounts of the polymer. For coating, the release rate of metominostrobin from the granules coated with the polymer (solid content: $50 \%$ ) by dropping process $[\mathrm{D}-1]$ was faster than that from the granules by fluidized bed process $[\mathrm{F}-1]$. For the solid content, the order of release rate from the granules was F-1 $>$ F-2 which was coated with the aqueous dispersion containing $5 \%$ solid content of the polymer by fluidized bed process. Superposition analysis on the release rates revealed that the difference in release mechanisms was dependent on the solid content of polymer but not on coating processes. Observation by SEM suggested that the release rate and release mechanism could correlate to each other and be related with the surface structure of the granules.
\end{abstract}

Key words: controlled release granule, coating condition, release profile, release mechanism, metominostrobin.

\section{INTRODUCTION}

In order to maintain the effects at the reduced amount of pesticides applied, controlled release formulation has been tried to prepare. There are many methods to prepare the formulation. For example, the granule containing activated carbon as a release-controlling agent and the microcapsule have been reported. ${ }^{1,2}$ Among the various controlled release formulation, it is relatively easy to adjust the release rate of active ingredient from granules which is coated with water insoluble polymer based on the amount of polymer. ${ }^{3,4)}$ However, even if the same amount of the polymer is used for test, there is a possibility that release profile and mechanisms may change by coating conditions.

In this study, we investigated the release profile of metominostrobin, $(E)$-2-methoxyimino- $N$-methyl-2(2-phenoxyphenyl)acetamide as a model agrochemical ${ }^{5,6)}$ from the granules prepared under different coating processes and solid content of the polymer.

\footnotetext{
* Studies on Controlled Release Granule Applied into Seedling Box (Part. 2) for Part. 1, see Ref. 4.
}

\section{MATERIALS AND METHODS}

\section{Chemicals}

The chemical structure of metominostrobin is shown in Fig. 1. It was synthesized at Aburahi Laboratories, Shionogi \& Co., Ltd. (Shiga, Japan). Polyvinyl alcohol (88\% hydrolysed; POVAL ${ }^{\circledR} 223-$-ss) was supplied by Kuraray \& Co., Ltd. (Tokyo, Japan). Calcium carbonate (12-24 mesh; Kansui \# 1224) was purchased from Nittou Funka Kogyo (Osaka, Japan). White carbon (CARPLEX ${ }^{\circledR} \# 80$ ) was supplied by Shionogi \& Co., Ltd. (Osaka, Japan). Aqueous vinyl acetate-acryl acid copolymer dispersion (VAA, solid content 50\%; Mowinyl ${ }^{\circledR}$ 630) used as a water insoluble, membraneforming agent was supplied by Hoechst Gosei \& Co., Ltd. (Tokyo, Japan). All other chemicals were of analytical grade and used without further purification.

\section{Preparation of Granules}

Table 1 showed the composition of the granules. Aqueous VAA copolymer dispersion was applied on metominostorobin-loaded uncoated granules by drop- 
<smiles>CO/N=C(\OC)c1ccccc1Oc1ccccc1</smiles>

Fig. 1 Chemical structure of metominostrobin.

Table 1 Composition of the granules (\%)

$\begin{array}{lr}\text { Metominostrobin } & 3.0 \\ \text { Polyvinyl alcohol } & 0.1 \\ \text { White carbon } & 0.1 \\ \text { Vinyl acetate-acryl acid copolymer } & 2.75 \\ \text { Calcium carbonate (12-24 mesh) } & 94.05\end{array}$

Total

100

ping process and fluidized bed process. The preparation of uncoated granule and coating process by dropping process is described in our previous report. ${ }^{4}$ In brief, metominostorobin was coated on calcium carbonate (1224 mesh) dropping 5\% (w/v\%) aqueous solution of polyvinyl alcohol. Then, the aqueous VAA copolymer dispersion including white carbon was dropped onto the granules. The granule was dried and sieved at 12/24 mesh.

The coating by fluidized bed process was conducted as below. The aqueous VAA copolymer dispersion including white carbon was sprayed onto the uncoated granules using fluidized bed granulator (Flow-Coater Mini, Freund Industrial Co., Ltd.). The spraying conditions were as follows: spray solution feed, $6 \mathrm{ml} / \mathrm{min}$; spray air pressure, $1.5 \mathrm{kgf} / \mathrm{cm}^{2}$; inlet temperature, $55^{\circ} \mathrm{C}$; outlet temperature, $36^{\circ} \mathrm{C}$. The coated granules were dried at $70^{\circ} \mathrm{C}$ for $20 \mathrm{~min}$ in the granulator. The granules containing $3.0 \%$ metominostrobin were obtained after sieving at $12 / 24$ mesh.

Thus, the granules which were prepared by dropping process was D-1 and the granules by fluidized bed process was F-1. The content of polymer on D-1 and F-1 was $50 \%$. The granules coated with the polymer at $5 \%$ by fluidized bed process was F-2.

\section{Determination of Release Rate}

Metominostrobin released from the granules was determined as previously described. ${ }^{2)}$

\section{Scanning Electron Microscopy (SEM)}

A scanning electron microscope (S800, Hitachi, Ltd., Tokyo) was used to observe the surface structure of coated granules. Each sample was sputter-coated with Pt-Pd alloy by an ion sputter before SEM-observation.

\section{RESULTS AND DISCUSSION}

1. Effects of Coating Conditions on Release Mechanisms of the Controlled Release Granules Coated with Water Insoluble Polymer

In coating, the aqueous VAA copolymer dispersion which contained $50 \%$ solid content was applied on the uncoated granules by dropping process and fluidized bed process. As shown in Fig. 2, the release rate of metominostrobin from D-1 coated by dropping process was faster than that from F-1 by fluidized bed process. The release rate from the granule, F-2, was smaller than that from F-1 (Fig. 3).

To see whether the release mechanism of metominostrobin could change when the coating conditions were altered, all the release profiles shown in Figs. 2 and 3 were normalized using the superposition method. The superposition method of the release curve using the reduced time $T_{r}$ as defined by the following equation is useful to compare the whole release patterns,

$$
T_{r}=t / T_{s}
$$

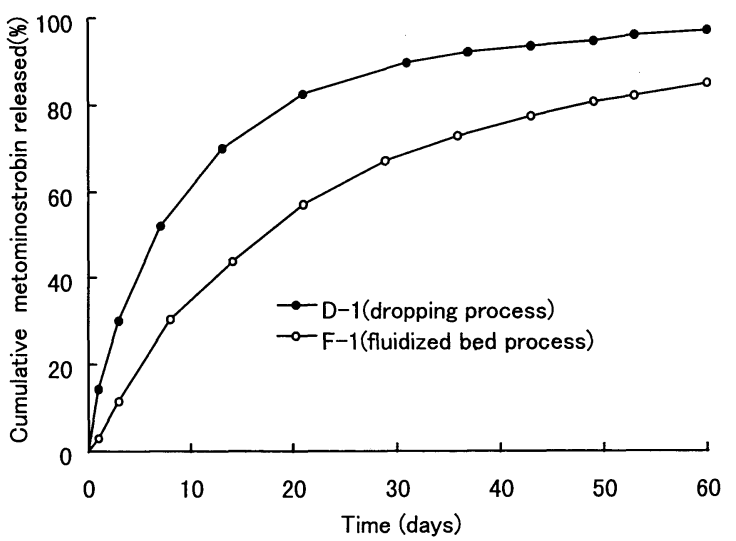

Fig. 2 Release profiles of metominostrobin from the granules D-1 and F-1 at $20^{\circ} \mathrm{C}$.

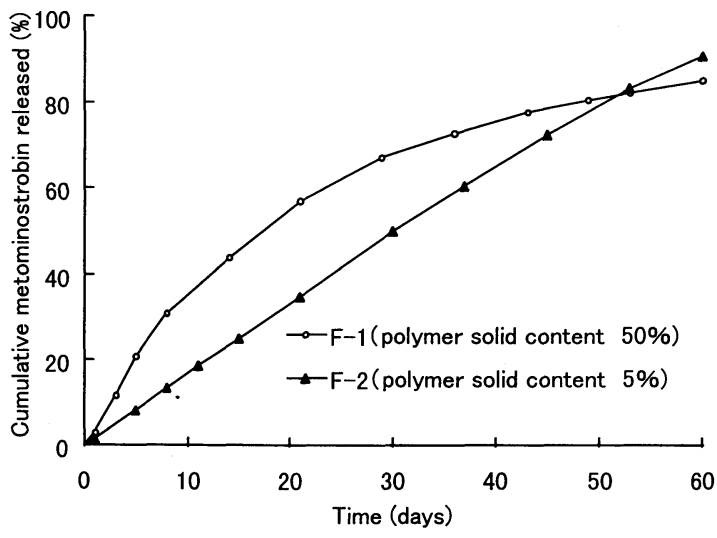

Fig. 3 Release profiles of metominostrobin from the granules $\mathrm{F}-1$ and $\mathrm{F}-2$ at $20^{\circ} \mathrm{C}$. 


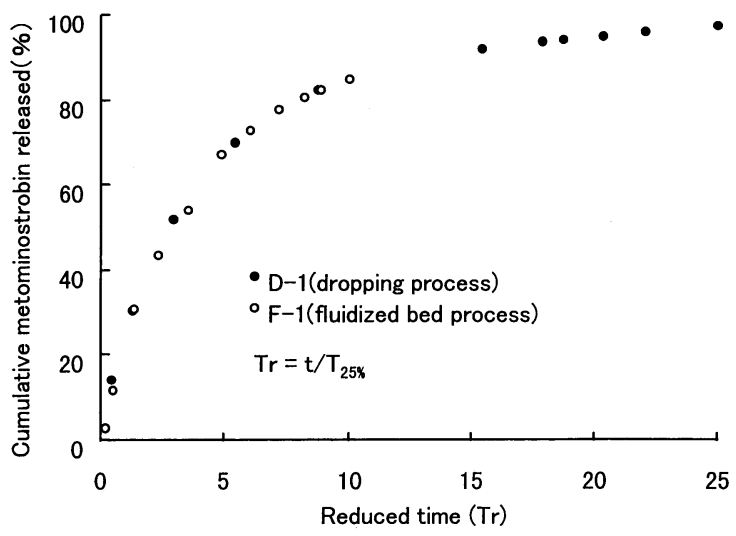

Fig. 4 Normalized release profiles of metominostrobin from the granules D-1 and F-1 at $20^{\circ} \mathrm{C}$.

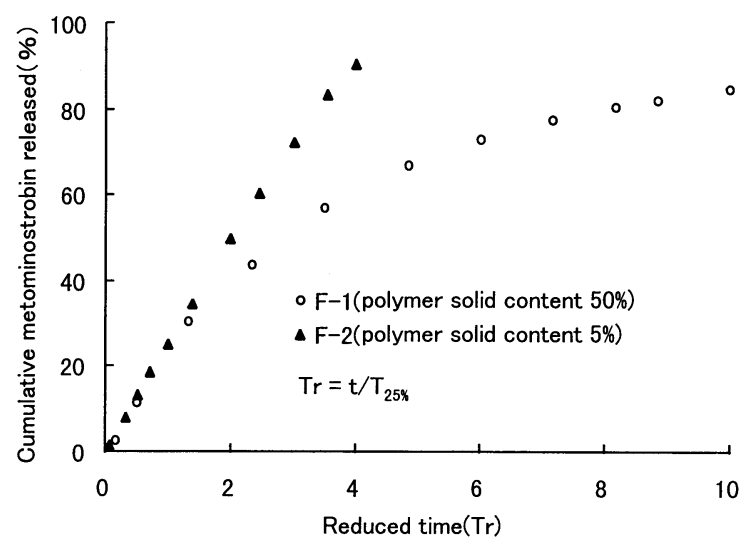

Fig. 5 Normalized release profiles of metominostrobin from the granules F-1 and F-2 at $20^{\circ} \mathrm{C}$.

where $t$ is the sampling time and $T_{s}$ is the time necessary for a definite amount of chemicals to be released from granules. Here, the quarter-release time $T_{25 \%}$ was chosen for $T_{s}$ because all the granules showed linear release at an early stage. If this release patterns are superposed perfectly, the release is thought to be regulated by the same mechanism. ${ }^{7)}$

The normalized profiles of D-1 and F-1 prepared by different coating processes were plotted in Fig. 4. They were well superposed, meaning that metominostrobin probably was released by the same mechanism and that only the release rate differed.

We also examined whether there were differences in release mechanisms between F-1 and F-2 (Fig. 5). Normalized plots of F-1 and F-2 showed discrepancies. This showed that the release mechanism of metominostrobin was affected by the content of coating polymer.

\section{The Surface Structure of Granules}

Scanning electron micrographs on the surface of D-1 and F-1 were shown in Figs. 6 a and b. The surface of D-1 was rougher and more porous as compared with F-1.
Thus, cracks and pores on the surface of granules prepared by dropping process seem to be more in number than that on the granules by fluidized bed process.

There were also differences between the surface of F-1 and F-2 in the number and size of pores, even though the same amount of VAA copolymer was coated on uncoated granules by the same process (Figs. $6 \mathrm{~b}$ and c). Namely the surface of F-2 was smoother as compared with that of F-1 and there was few large pores on the surface of the granules. The reason why the difference in the number and size of pores existed could be due to the difference in the droplet size ${ }^{8,9)}$ and the viscosity ${ }^{10,11)}$ of the polymer solution.

Thus, the appearance on the surface of granules was found to be certainly affected by the coating process and the content of polymer. The release profiles and mechanism can be dependent on these appearance.

\section{The Relationship between Coating Condition and Release Mechanism}

There are some release mechanisms of capsule-type controlled release forms coated with water insoluble polymer. ${ }^{12,13)}$ The mechanisms are as follows :

A) diffusion through internally connecting channels such as aqueous pores or minute cracks.

B) diffusion through a continuous polymer phase.

C) diffusion through a continuous polymer phase in parallel with diffusion through aqueous pores or minute cracks.

Whichever mechanism, A) or B), is predominant, the release rate is zero order, if the nature of the coated-film does not change throughout the release test. ${ }^{12)}$

If a drug is released from granules according to C), which is the most usual combination, a linear relationship at the beginning of the release between time and released percent is obtained because a sufficient amount of the drug would be present to maintain a constant concentration in the internal phase of the coated granules. ${ }^{13)}$

From the results of release profile, superposition analysis and SEM observation, the release mechanism of D-1 and F-1 would be C), because release rates are zero order at the beginning of release and pores could be observed by SEM. On the other hand, the release mechanism of F-2 would be B), because the release profile is zero order throughout the release test and few pores could be observed by SEM.

In conclusion, the release rate and mechanism of metominostrobin from the granules were regulated by the coating process and the content of polymer.

\section{ACKNOWLEDGMENTS}

The authors are grateful to Dr. Katsuaki Ohba, Shionogi Aburahi Laboratories, for his many helpful suggestions during the observation of SEM. 


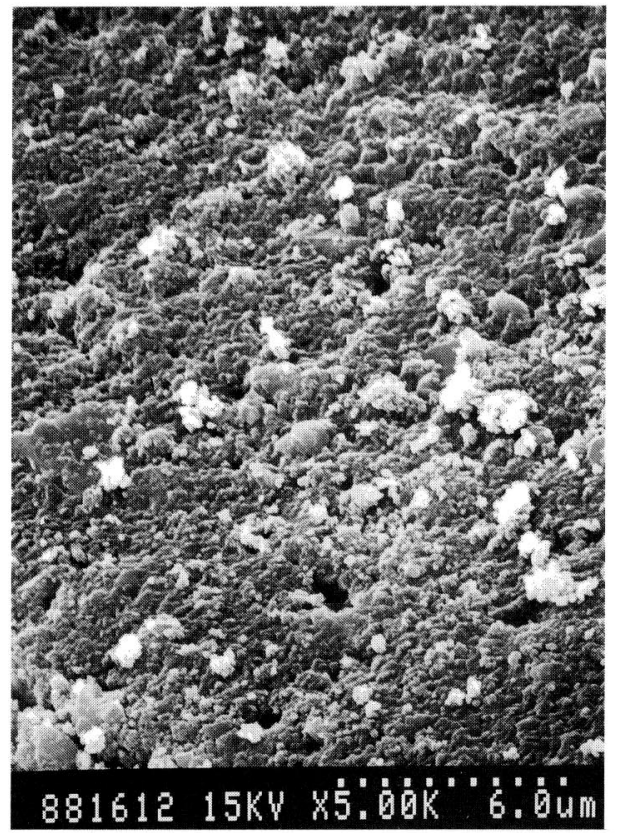

(a)

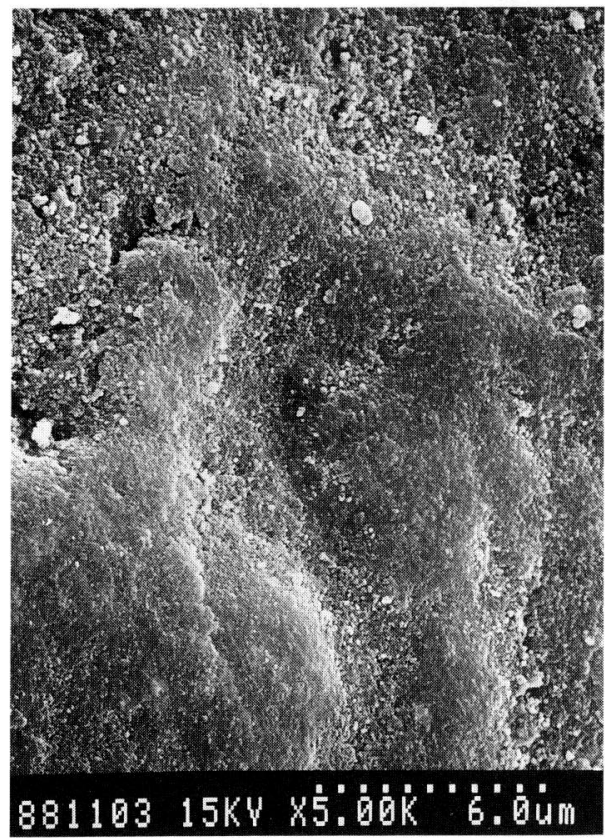

(c)

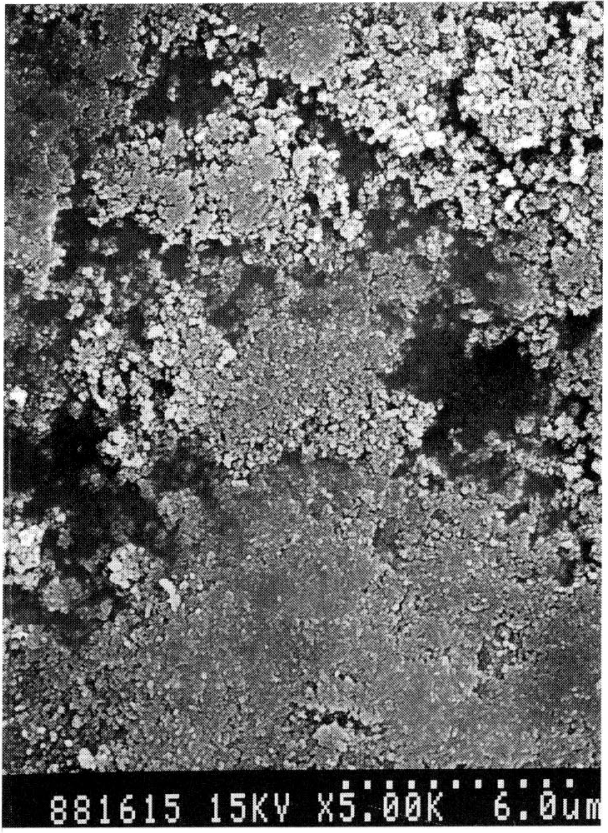

(b)

Fig. 6 Scanning electron micrographs on the surface of the granules D-1; (a), F-1; (b) and F-2; (c).

Nihon Sekiyu): Jpn. Kokai Tokkyo Koho JP60202801(1984)

\section{REFERENCES}

1) R. Kume, S. Tashima, K. Matsumoto, I. Ando \& T. Shiraishi: J. Pesticide Sci. 21, 404 (1996)

2) T. Ohtsubo, H. Takeda, S. Tsuda, M. Kagoshima \& K. Tsuji: J. Pesticide Sci. 14, 235 (1989)

3) Y. Wada, A. Simomatsu, T. Nakahara, S. Uzawa, S. Suzuki \& N. Okayama (Nihon Tokusyu Nouyaku Co. Ltd. and

4) S. Tashima, A. Kawaguchi, H. Kashino, K. Matsumoto, I. Ando, R. Takeda \& T. Shiraishi: J. Pesticide Sci. 24, 287 (1999)

5) M. Masuko, T. Kataoka, M. Niikawa, M. Ichinari, H. Takenaka, Y. Hayase, Y. Hayashi \& R. Takeda: Abstr.; 8th IUPAC Int. Congr. Pestic. Chem., Washington, D.C., P898 (1994) 
6) Y. Hayase, T. Kataoka, M. Masuko, M. Niikawa, M. Ichinari, H. Takenaka, T. Takahashi, Y. Hayashi \& R. Takeda: Proc. of "Synthesis \& Chemistry of Agrochemicals IV : ACS Symposium Series 584,” Am. Chem. Soc. Washington, D.C., P343 (1995)

7) S. Narisawa, H. Yoshino, Y. Hirasawa \& K. Noda: Chem. Pharm. Bull. 42, 1485 (1994)

8) S. Watano, K. Fukushima \& K. Miyanami: J. Chem. Eng. Jpn. 28, 8 (1995)

9) S. Watano, A. Yamamoto \& K. Miyanami: Chem. Pharm. Bull. 44, 2128 (1996)

10) M. E. Aulton, A. M. Twitchell \& J. E. Hogan: "Aqueous Polymeric Coatings for Pharmaceutical Dosage Forms," ed. by W. McGinity, Vol. 79, Marcel Dekker Inc, New York, P227 (1997)

11) S. Watano, H. Takaya, I. Wada \& K. Miyanami: Chem. Pharm. Bull. 42, 2338 (1996)

12) Y. Koida, H. Takahata, M. Kobayashi \& M. Samejima: Chem. Pharm. Bull. 35, 1538 (1987)

13) T. Maejima, T. Osawa, K. Nakajima \& M. Kobayashi: Chem. Pharm. Bull. 45, 904 (1997)
要 約

疎水性高分子で被覆した放出制御粒剤の溶出挙動に おける被覆条件の影響*

田島 繁, 松本公平, 安藤 嚴, 武田禮二, 白石友紀 モデル薬物としてメトミノストロビンを用い，粒剂表面 を踈水性高分子で被覆した徐放性粒剤からの溶出挙動にお よぼす被覆方法（高分子液の滴下または流動層造粒機によ る被覆）と被覆液中の高分子濃度（5および $50 \%)$ の影響を 調べた。その結果，1）高分子濃度 50\%の被覆液を用いて滴 下または流動層造粒機で被覆した場合, 薬物の放出速度は 滴下による被覆法>流動層造粒機による被覆法であった が，溶出機構は同一であった，2)流動層造粒機による被覆 の場合，薬物の放出速度は高分子濃度 $5 \%<50 \% て ゙ ，$ 溶出機 構が異なった。これらの原因は，粒剂表面の被覆膜におけ る細孔の大きさや数の違いによることが示唆された。

*放出制御された育苗箱施用粒剂に関する研究（第 2 報） 